ФІЗІОЛОГО-БОХІМІЧНІ ПОКАЗНИКИ КРОВІ КОРІВ ЗА

ЗГОДОВУВАННЯ ДОБАВКИ АКВАГІДРАТУ ЙОДУ І ЦИТРАТІВ

ХРОМУ, СЕЛЕНУ, КОБАЛЬТУ ТА ЦИНКУ

М. М. ЦАП, кандидат сільськогосподарських наук

Інститут біології тварин НААН

В. Г. КАПЛУНЕНКО, доктор технічних наук

Украӥнський державний науково-дослідний

інститут нанобіотехнологій та ресурсозбереження

Р. С. ФЕДОРУК, доктор ветеринарних наук, член-кореспондент НААН

I. І. КОВАЛЬЧУК, доктор ветеринарних наук, старший науковий співробітник

О. П. ДОЛАЙЧУК, кандидат біологічних наук

М. І. ХРАБКО, кандидат сільськогосподарських наук

Інститут біології тварин НААН

E-mail: ecology@inenbiol.com.ua

Анотація. У статті наведено результати досліджень впливу введення в раціон корів добавки з аквагідрату йоду і цитратів хрому, селену, кобальту та цинку, що були отримані методом нанотехнології, на протікання фізіологічних процесів в організмі за рівнем гематологічних та імунобіологічних показників, а також вміст окремих мікроелементів у крові корів. Відзначено, що включення до раиіону корів добавки з аквагідрату йоду та иитратів хрому $і$ селену (0,06 мг I, 30 мкг Cr, 25 мкг Se/кг с. р. рачіону) протягом двох місящів сприяло посиленню обміну глікопротеїнів та їх вуглеводних компонентів з вірогідним збільшенням у крові тварин вмісту иерулоплазміну, сіалових кислот і гексоз, зв'язаних із білками. Суттєвого виливу добавки на рівень інших імунологічних та гематологічних показників не було відмічено. Застосування у годівлі корів у перший місящь лактащії добавки, що містила Йод, Хром, Селен, Кобальт та Цинк (0,06 мг I, 30 мкг Cr, 25 мкг Se, 100 мкг Со та 10 мг Zn/кг с. p. раиіону), зумовлювало вірогідне підвищення вмісту у крові тварин Купруму, у другий місящь згодовування добавки - вірогідне підвищення вмісту Кобальту, Купруму та зниження Кадмію.

Ключові слова: корови, кров, мінеральна добавка, аквагідрат йоду, цитрати хрому, селену, кобальту, иинку, гемоглобін, еритроцити, загальний білок, амінотрансферази, молекули середньої маси, ичикулюючі імунні комплекси, глікопротеїни, мікроелементи 
Мінеральні елементи відіграють важливу роль в організмі тварин. Вони беруть участь в регуляції вуглеводного, жирового і білкового обмінів, швидкості біохімічних реакцій, метаболізму вітамінів, процесах росту i розвитку $[1,2]$. Йод необхідний для синтезу гормонів щитоподібної залози, які $\epsilon$ важливими для росту і розвитку всіх органів [3-5]. Хром бере участь у транспортуванні білків, нормалізує функцію щитоподібної залози і стимулює процеси регенерації. Він забезпечує профілактику остеопорозу, зміцнює кісткову тканину $[2,6]$. Селен - біологічно активний мікроелемент, що входить до низки гормонів і ферментів та пов'язаний з діяльністю всіх органів, тканин і систем. Селен бере участь в процесах відтворення, розвитку молодого організму і є одним 3 ключових мікроелементів, що забезпечує нормальну функцію ферментативної ланки антиоксидантної системи організму [7, 8]. Кобальт входить до компонентів вітаміну $\mathrm{B}_{12}$, активно бере участь у ферментативних процесах і утворенні гормонів щитоподібної залози, стимулює кровоутворення. Кобальт підвищує засвоюваність Феруму і синтез гемоглобіну, $\epsilon$ стимулятором еритропоезу. Він необхідний для утворення еритроцитів та інших формених елементів крові $[1,2]$. Цинк $є$ важливим компонентом низки металоферментів, таких як карбоангідраза, лужна фосфатаза тощо. Цинк відіграє важливу роль у метаболізмі РНК і ДНК, у функціонуванні Т-клітинної ланки імунітету, в метаболізмі ліпідів і білків. Він здатний коригувати адаптаційні механізми, збільшувати об'ємні і транспортні властивості гемоглобіну стосовно кисню. Вважають, що цинк має антиоксидантні властивості, а також покращує дію інших антиоксидантів $[1,2,9]$.

Аналіз останніх джерел та публікацій. На сьогоднішній день для забезпечення потреб тваринництва у мінеральних добавках найбільш перспективними є органічні сполуки макро- і мікроелементів, що отримані методами нанотехнологій. [10, 11]. Унікальність наноматеріалів пов'язана 3 їхньою високою хімічною і біологічною активністю та здатністю впливати на метаболічні процеси [10]. Особливої уваги заслуговують цитрати мікроелементів, що входять до мінеральних преміксів і кормових добавок та 
використовуються для балансування мінерального живлення у раціонах тварин. Рівень засвоєння та ефективність біологічної дії таких сполук у декілька разів вищі, ніж з мінеральних солей цих елементів.

Мета досліджень - вивчення впливу введення до раціону наноаквахелатних розчинів мікроелементів на фізіолого-біохімічні процеси в крові корів у перший період лактації.

Матеріали і методи досліджень. Дослідження були проведені в ДП «ДГ Пасічна» на 15 повновікових коровах української чорно-рябої молочної породи, аналогах за продуктивністю (6,5-6,8 тис кг молока за лактацію), віком (3-4 лактація), масою тіла (590-650 кг), періодом лактації (1-й місяць після отелення). У підготовчий період (15 діб) корів було розділено на 3 групи. Тварини I - контрольної і II та III дослідних груп у підготовчий період отримували основний раціон (ОР), збалансований за поживністю. У дослідний період (75 діб) коровам II дослідної групи згодовували корми ОР разом 3 добавкою гідрату йоду і цитратів хрому, селену, кобальту та цинку $(0,06$ мг I, 30 мкг $\mathrm{Cr}, 25$ мкг Se, 100 мкг Со та 10 мг Zn/кг с. p. раціону), а тваринам III дослідної групи - ОР з додаванням гідрату йоду та цитратів хрому і селену (0,06 мг I, 30 мкг $\mathrm{Cr}$ i 25 мкг Se/кг с. p. раціону). Гідрат йоду і цитрати мікроелементів, виготовлені методом М. Косінова і В. Каплуненка [11] 3 використанням нанотехнології, згодовували коровам дослідних груп щоденно впродовж двох місяців лактації з добовою порцією комбікорму. Дослідження тривали 90 діб.

Для біохімічних досліджень відбиралися зразки венозної крові у підготовчий (за 7-10 діб до введення до раціону добавок) і дослідний (30 і 60 доби згодовування добавок) періоди. У крові визначали: кількість еритроцитів, вміст гемоглобіну, загального білка, молекул середньої маси, циркулюючих імунних комплексів, церулоплазміну, гаптоглобіну, сіалових кислот, гексоз, зв'язаних 3 білками, активність аланін- та аспартатамінотрансфераз, концентрацію $\mathrm{Co}, \mathrm{Zn}, \mathrm{Cu}, \mathrm{Mn}$ i Cd за методами, що описані в довіднику [12].

Результати досліджень та їх обговорення. Застосування в годівлі корів у 
перший місяць лактації добавки Йоду, Хрому, Селену, Кобальту та Цинку зумовлювало підвищення вмісту Купруму у крові тварин II дослідної групи на $28,5 \%$ ( $>$ < 0,05) та невірогідне зростання рівня Кобальту і Мангану, а також зниження Кадмію та Цинку (табл. 1). На другому місяці згодовування добавки відмічалося підвищення у крові тварин цієї групи вмісту Кобальту на 36,8 \% (р $<0,05)$, Купруму - на 36,5 \% ( < 0,05) та зниження Кадмію на 23,5 \% (p < $0,05)$.

Застосування протягом періоду досліджень I, $\mathrm{Cr}$ i $\mathrm{Se}$, сприяло збільшенню у крові корів III дослідної групи вмісту Купруму відповідно на 1 і 2 місяцях на 21,5 та 24,0 \% ( < 0,05). Зміни вмісту інших досліджуваних мікроелементів як на першому, так і на другому місяцях згодовування добавки були аналогічні тваринам II дослідної групи.

Отримані результати вказують на вірогідно виражену синергічну дію гідрату йоду на вміст $\mathrm{Cu}$ у крові корів II і III груп впродовж всього періоду досліджень, що може зумовлюватися посиленням використання Сu у травному тракті з кормів раціону $[1,2]$.

1. Вміст мікроелементів у крові корів (мг/л, $\mathrm{M} \pm \mathbf{m}, \mathbf{n}=4$ )

\begin{tabular}{|c|c|c|c|c|}
\hline \multirow{2}{*}{$\begin{array}{c}\text { Мікро } \\
\text { елемент }\end{array}$} & \multirow{2}{*}{ Група } & \multicolumn{3}{|c|}{ Період дослідження } \\
\cline { 3 - 5 } & & підготовчий & \multicolumn{2}{|c|}{ дослідний, місяць згодовування } \\
\cline { 3 - 5 } & I & $0,072 \pm 0,006$ & $0,078 \pm 0,008$ & $0,076 \pm 0,005$ \\
Co & II & $0,076 \pm 0,009$ & $0,094 \pm 0,004$ & $0,104 \pm 0,004 * *$ \\
& III & $0,071 \pm 0,006$ & $0,081 \pm 0,006$ & $0,084 \pm 0,004$ \\
\hline \multirow{2}{*}{$\mathrm{Zn}$} & I & $2,412 \pm 0,198$ & $2,132 \pm 0,178$ & $2,049 \pm 0,140$ \\
& II & $2,249 \pm 0,209$ & $1,857 \pm 0,187$ & $1,864 \pm 0,246$ \\
& III & $2,215 \pm 0,242$ & $2,030 \pm 0,336$ & $1,993 \pm 0,118$ \\
\hline \multirow{2}{*}{$\mathrm{Cu}$} & I & $0,514 \pm 0,036$ & $0,650 \pm 0,050$ & $0,643 \pm 0,047$ \\
& II & $0,525 \pm 0,040$ & $0,835 \pm 0,053^{*}$ & $0,878 \pm 0,077 *$ \\
& III & $0,539 \pm 0,038$ & $0,790 \pm 0,030^{*}$ & $0,797 \pm 0,035^{*}$ \\
\hline \multirow{2}{*}{$\mathrm{Mn}$} & I & $0,151 \pm 0,011$ & $0,176 \pm 0,014$ & $0,187 \pm 0,014$ \\
& II & $0,158 \pm 0,011$ & $0,211 \pm 0,013$ & $0,212 \pm 0,011$ \\
& III & $0,155 \pm 0,012$ & $0,199 \pm 0,015$ & $0,192 \pm 0,011$ \\
\hline \multirow{2}{*}{$\mathrm{Cd}$} & I & $0,018 \pm 0,001$ & $0,018 \pm 0,002$ & $0,017 \pm 0,001$ \\
& II & $0,019 \pm 0,001$ & $0,014 \pm 0,001$ & $0,013 \pm 0,001^{*}$ \\
\hline
\end{tabular}

Примітки: $y$ цій $i$ наступних таблицях різниия статистично вірогідна порівняно $з$ першою групою $*-P<0,05 ; * *-P<0,01 ; * * *-P<0,001$

Підсилювати синергічний вплив I на вміст $\mathrm{Cu}$ можуть також введені до 
раціону цитрати $\mathrm{Cr}$ i Se. Тим часом антагонічний вплив Co i $\mathrm{Zn}$ супроводжувався не вірогідно вираженою тенденцією до нижчого рівня Zn y крові корів II групи як на 1-му, так і на 2-му місяцях згодовування мінеральної добавки. Певний стимулюючий вплив гідрат йоду і цитрати $\mathrm{Cr}$ тa $\mathrm{Se}$ зумовлювали і на вміст Mn, рівень якого був вищим у крові корів обох дослідних груп упродовж досліджень. На синергічний зв'язок Co, I i $\mathrm{Cu}$ вказують результати досліджень й інших авторів [3, 9], проте такий зв'язок $\mathrm{Mn}$ i Se потребує ще експериментального підтвердження.

За результатами досліджень встановлено, що добавка мікроелементів не мала суттєвого впливу на досліджувані біохімічні показники крові корів II та III дослідних груп (табл. 2). Міжгрупові відмінності кількості еритроцитів, вмісту гемоглобіну, загального білка, ЦІК і МСМ, а також активності АлАТ і АсАТ у крові корів дослідних і контрольної груп були незначними і знаходилися в межах статистичних відхилень їх середніх величин.

2. Біохімічні показники крові корів $(\mathrm{M} \pm \mathrm{m}, \mathbf{n}=3-4)$

\begin{tabular}{|c|c|c|c|c|}
\hline \multirow{3}{*}{ Показник } & \multirow{3}{*}{ Група } & \multicolumn{3}{|c|}{ Період дослідження } \\
\hline & & \multirow{2}{*}{ підготовчий } & \multicolumn{2}{|c|}{ дослідний, місяць згодовування } \\
\hline & & & 1 & 2 \\
\hline \multirow{3}{*}{$\begin{array}{c}\text { Гемоглобін, } \\
\text { г/л }\end{array}$} & I & $106,9 \pm 2,98$ & $94,3 \pm 2,96$ & $95,3 \pm 4,31$ \\
\hline & II & $110,5 \pm 4,06$ & $88,8 \pm 3,20$ & $85,3 \pm 6,98$ \\
\hline & III & $120,9 \pm 5,43$ & $93,0 \pm 3,24$ & $92,0 \pm 3,44$ \\
\hline \multirow{3}{*}{$\begin{array}{c}\text { Еритроцити, } \\
\text { Т/л }\end{array}$} & $\mathrm{I}$ & $5,53 \pm 0,74$ & $5,28 \pm 0,17$ & $5,62 \pm 0,42$ \\
\hline & II & $5,36 \pm 0,24$ & $5,52 \pm 0,16$ & $5,21 \pm 0,42$ \\
\hline & III & $6,12 \pm 0,14$ & $5,53 \pm 0,23$ & $5,53 \pm 0,19$ \\
\hline \multirow{3}{*}{$\begin{array}{c}\text { Загальний білок, } \\
\text { г/л }\end{array}$} & $\mathrm{I}$ & $87,0 \pm 2,60$ & $88,5 \pm 3,43$ & $93,2 \pm 3,14$ \\
\hline & II & $91,0 \pm 3,32$ & $91,2 \pm 1,88$ & $92,8 \pm 3,09$ \\
\hline & III & $89,8 \pm 0,95$ & $95,0 \pm 1,47$ & $86,9 \pm 1,65$ \\
\hline \multirow{3}{*}{ АлАТ, мкат/л } & I & $27,7 \pm 1,71$ & $30,9 \pm 3,03$ & $29,2 \pm 3,25$ \\
\hline & II & $33,0 \pm 2,91$ & $37,0 \pm 4,93$ & $36,0 \pm 5,40$ \\
\hline & III & $33,3 \pm 2,52$ & $30,5 \pm 0,63$ & $30,9 \pm 2,23$ \\
\hline \multirow{3}{*}{ АсАТ, мкат/л } & $\mathrm{I}$ & $83,2 \pm 2,31$ & $74,5 \pm 8,31$ & $66,7 \pm 5,12$ \\
\hline & II & $86,2 \pm 7,83$ & $83,7 \pm 8,19$ & $76,1 \pm 3,18$ \\
\hline & III & $92,8 \pm 10,24$ & $82,4 \pm 3,13$ & $71,8 \pm 3,84$ \\
\hline \multirow{3}{*}{ MCM, у.о. } & I & $0,102 \pm 0,009$ & $0,082 \pm 0,009$ & $0,109 \pm 0,012$ \\
\hline & II & $0,107 \pm 0,022$ & $0,082 \pm 0,005$ & $0,101 \pm 0,010$ \\
\hline & III & $0,097 \pm 0,012$ & $0,091+0,003$ & $0,108 \pm 0,008$ \\
\hline \multirow{3}{*}{ ЦІК, ммоль/л } & I & $69,75 \pm 7,48$ & $98,25+6,06$ & $96,50+3,23$ \\
\hline & II & $67,50 \pm 4,35$ & $91,00+4,59$ & $95,50+6,76$ \\
\hline & III & $65,25 \pm 7,26$ & $90,60+3,51$ & $100,00+2,81$ \\
\hline
\end{tabular}

Вивчення рівня глікопротеїнів та їх вуглеводневих компонентів у крові 
корів контрольної та дослідних груп вказує на коригуючий вплив використаних добавок на імунобіологічну реактивність їхнього організму (табл. 3). Про це свідчить вищий, проте в межах фізіологічних коливань, рівень глікопротеїнів та окремих моноцукрів їх вуглеводних компонентів у крові тварин дослідних груп порівняно із контролем. Однак більш виражений фізіологічний ефект від додавання до раціону тварин II i III груп комплексу аквагідрату йоду 3 цитратами мікроелементів встановлено для Хрому та Селену, що використані у III групі. Біологічний вплив супроводжувався вірогідним підвищенням концентрації церулоплазміну, сіалових кислот (в обох групах) i гексоз, зв’язаних із білками в крові корів цієї групи і невірогідно - в II групі вже через місяць після початку дослідного періоду. Вищий рівень зазначених глікопротеїнів у крові корів обох груп стосовно контролю зберігався також на 2-му місяці згодовування до завершення досліду.

3. Вміст глікопротеїнів у крові корів $(\mathrm{M} \pm \mathrm{m}, \mathrm{n}=3-4)$

\begin{tabular}{|c|c|c|c|c|}
\hline \multirow{3}{*}{ Показник } & \multirow{3}{*}{ Група } & \multicolumn{3}{|c|}{ Період дослідження } \\
\hline & & \multirow{2}{*}{ підготовчий } & \multicolumn{2}{|c|}{ дослідний, місяць згодовування } \\
\hline & & & 1 & 2 \\
\hline \multirow{3}{*}{$\begin{array}{l}\text { Церулоплазмін, } \\
\text { у. о. }\end{array}$} & $\mathrm{I}$ & $349,3 \pm 12,49$ & $306,0 \pm 7,72$ & $280,8 \pm 13,37$ \\
\hline & II & $355,5 \pm 19,78$ & $334,6 \pm 9,64$ & $356,3 \pm 7,02 *$ \\
\hline & III & $345,8 \pm 19,67$ & $344,0 \pm 9,22 *$ & $336,4 \pm 14,63^{*}$ \\
\hline \multirow{3}{*}{$\begin{array}{l}\text { Гаптоглобін, } \\
\text { г/л }\end{array}$} & $\mathrm{I}$ & $3,21 \pm 0,057$ & $3,61 \pm 0,064$ & $3,43 \pm 0,063$ \\
\hline & II & $3,07 \pm 0,083$ & $3,61 \pm 0,070$ & $3,53 \pm 0,079$ \\
\hline & III & $3,04 \pm 0,059$ & $3,63 \pm 0,081$ & $3,49 \pm 0,065$ \\
\hline \multirow{3}{*}{$\begin{array}{l}\text { Сіалові кислоти, } \\
\text { у. о. }\end{array}$} & I & $131,0 \pm 9,28$ & $140,5 \pm 2,40$ & $153,0 \pm 4,60$ \\
\hline & II & $144,8 \pm 7,16$ & $164,3 \pm 7,82^{*}$ & $181,0 \pm 6,89^{*}$ \\
\hline & III & $143,5 \pm 6,89$ & $179,8 \pm 10,62 *$ & $182,3 \pm 3,99 * *$ \\
\hline \multirow{3}{*}{$\begin{array}{l}\text { Гексози, зв’язані } з \\
\text { білками, г/л }\end{array}$} & I & $2,69 \pm 0,09$ & $2,75 \pm 0,082$ & $2,33 \pm 0,075$ \\
\hline & II & $2,75 \pm 0,08$ & $2,95 \pm 0,065$ & $2,48 \pm 0,057$ \\
\hline & III & $2,79 \pm 0,08$ & $3,04 \pm 0,063 *$ & $2,63 \pm 0,106^{*}$ \\
\hline
\end{tabular}

В той час як у крові тварин II групи, які окрім аквагідрату йоду та цитратів хрому і селену отримували ще й цитрати кобальту та цинку, підвищення концентрації церулоплазміну та гексоз, зв'язаних із білками, залишалось на рівні тенденції у перший місяць дослідного періоду, а вірогідне зростання відмічено лише для церулоплазміну на 60 добу згодовування добавок. Вміст 
сіалових кислот вірогідно зростав у крові тварин II групи на першому і другому місяцях досліджень. Такі незначні відмінності впливу поєднання 3 I двох мікроелементів на рівень глікопротеїнів у крові корів II і III груп можуть свідчити як про синергічні зв'язки окремих застосованих мікроелементів, так i про різну фізіологічну дію залежно від тривалості їхнього застосування для прояву бажаного ефекту.

Висновки і перспективи подальших досліджень. Застосування у годівлі корів у перший місяць лактації добавки, що містила Йод, Хром, Селен, Кобальт та Цинк (0,06 мг I, 30 мкг Cr, 25 мкг Se, 100 мкг Cо та 10 мг Zn/кг с. p. раціону), зумовлювало вірогідне підвищення вмісту Купруму, у другий місяць згодовування добавки - вірогідне підвищення у крові тварин вмісту Кобальту, Купруму та зниження Кадмію. Включення до раціону корів добавки з гідрату йоду та цитратів хрому і селену (0,06 мг I, 30 мкг Cr, 25 мкг Se/кг с. p. раціону) протягом двох місяців сприяло активації обміну глікопротеїнів та їх моноцукрів 3 вірогідним збільшенням у крові тварин вмісту церулоплазміну, сіалових кислот і гексоз, зв'язаних із білками.

У подальших дослідженнях доцільним $є$ вивчення впливу згодовування цих сполук на біологічну цінність та якість молока, а також репродуктивну здатність корів.

\section{Список літератури}

1. Погорєлов, М. В. Макро-та мікроелементи (обмін, патологія та методи визначення) [текс] / М. В. Погорєлов, В. І. Бумейстер, Г. Ф. Ткач. - Суми: Видво СумДУ, 2010. - 147 с.

2. Захаренко, М. Роль мікроелементів у життєдіяльності тварин / М. Захаренко, Л. Шевченко, В. Михальська // Ветеринарна медицина України. 2004. - № 2. - C. 15.

3. Антоняк, Г. Л. Біохімічна та геохімічна роль Йоду: монографія / Г. Л. Антоняк, В. В. Влізло. - Львів: ЛНУ ім. Івана Франка, 2013. - 392 с.

4. Вплив уведення йоду до раціону самок $\mathrm{i}$ самців щурів на фізіологічні показники організму i гістологію щитоподібної залози / О. П. Долайчук, Р. С. Федорук, І. І. Ковальчук [та ін.] // Вісник ЛНУВМіБТ. 2014. - Т. 16. - №2 (59). - Ч. 2. - С. 106-113.

5. Aceves, C. The extrathyronine actions of iodine as antioxidant, apoptotic and differentiation factor in various tissues / C. Aceves, B. Anguiano, G. Delgado // Thyroid. - 2013. - Vol. 23, № 8. - P. 938-46. 
6. Хром у живленні тварин / [Р. Я. Іскра, В. В. Влізло, Р. С. Федорук, Г. Л. Антоняк]. - К.: Аграрна наука, 2014. - 312 с.

7. Снітинський, В. В. Біохімічна роль Селену / В.В.Снітинський, Г. Л. Антоняк // Український біохімічний журнал. - 1994. - Вип. 66. - № 5. C. 3-16.

8. Біохімічні основи нормування мінерального живлення великої рогатої худоби. 2. Мікроелементи / В. В. Влізло, Л. І. Сологуб, В. Г. Янович [та ін.] // Біологія тварин. - 2006. - Т. 8, № 1-2. - С. 41-62.

9. Скальный, А. В. Биоэлементы в медицине / А. В. Скальный, И. А. Рудаков. - М.: Издательский дом «Оникс 21 век» : Мир, 2004. - 272 с.

10. Наноматеріали в біології. Основи нановетеринарії / В. Б. Борисевич, В. Г. Каплуненко, М. В. Косінов [та ін.]; за ред. В. Б. Борисевича, В. Г. Каплуненка. - К.: «Авіцена», 2010. - 416 с.

11. Патент України на корисну модель № 29856. Спосіб отримання аквахелатів нанометалів «Ерозійно-вибухова нанотехнологія отримання аквахелатів нанометалів» / М. В. Косінов, В. Г. Каплуненко // МПК (2006): В01 J 13/00, В82В 3/00, Опубл. 25.01.2008, Бюл. № 2/2008.

12. Лабораторні методи досліджень у біології, тваринництві та ветеринарній медицині / В. В. Влізло, Р. С. Федорук, І. Б. Ратич [та ін.]; за ред. В. В. Влізло. - Львів: Сполом, 2012. - 762 с.

\section{References}

1. Pohorielov, M. V., Bumeister, V. I., Tkach, H. F. (2010). Makro-ta mikroelementy (obmin, patolohiia ta metody vyznachennia) [Macro-and micronutrients (metabolism, pathology and determination methods)]. Sumy, Ukraine: Edition SumDU, 147.

2. Zakharenko, M., Shevchenko, L., Mykhalska, V. (2004). Rol mikroelementiv u zhyttiediialnosti tvaryn [The role of trace elements in animal life]. Veterinary medicine of Ukraine: $2,15$.

3. Antoniak, H. L., Vlizlo, V. V. (2013). Biokhimichna ta heokhimichna rol Yodu [Biochemical and geochemical role of Iodine]. Lviv, Ukrainian, 392.

4. Dolaychuk, O. P., Fedoruk, R. S., Kovalchuk, I. I., Kropyvka, S. I., Tsap, M. M. (2014). Vplyv uvedennia yodu do ratsionu samok i samtsiv shchuriv na fiziolohichni pokaznyky orhanizmu i histolohiiu shchytopodibnoi zalozy [Physiological data and histology of the thyroid gland of the female and male rats under conditions of watering iodine]. Visnyk LNUVM and BT, 16, 2 (59), 2, 106113.

5. Aceves, C., Anguiano, B., Delgado G. (2013). The extrathyronine actions of iodine as antioxidant, apoptotic and differentiation factor in various tissues. Thyroid, 23, 8, 938-46.

6. Vlizlo, V. V., Iskra, R. Ia., Fedoruk, R. S., Antoniak, H. L. (2014). Khrom u zhyvlenni tvaryn [Chromium in animal nutrition]. Kyiv, Ulraine : Ahrarna nauka, 312.

7. Snitynskyi, V. V., Antoniak, H. L. (1994). Biokhimichna rol Selenu [Biochemical role of selenium]. Ukrainian Journal of Biochemistry: 66, 5, 3- 16. 
8. Vlizlo, V. V., Solohub, L. I., Yanovych, V. H. At al. (2006). Biokhimichni osnovy normuvannia mineralnoho zhyvlennia velykoi rohatoi khudoby. 2. Mikroelementy [Biochemical basis of valuation of mineral nutrition of cattle. 2. Micronutrients]. The Animal Biology, 8, 1-2, 41-62.

9. Skalnyi, A. V., Rudakov, I. A. (2004). Byoelementy v medytsyne [Bioelements in medicine]. Moscow, Russia: Izdatelskiy Dom, "Onyx 21 vek": Mir, 272.

10. Borysevych, V. B., Kaplunenko, V. H., Kosinov, M. V. at al. (2010). Nanomaterialy v biolohii. Osnovy nanoveterynarii [Nanomaterials in biology. Basics of nanoveterinary medicine]. Kyiv, Ukraine : «Avitsena», 416.

11. Kosinov, M. V., Kaplunenko, V. H. (2008). Method receiving of akvahelat nanometals "Erosion-explosive nanotechnology receiving of akvahelat nanometals". Patent of Ukraine for useful model. B01J 13/00, B82B 3/00. № 29856. Published 25.01.2008, 2.

12. Vlizlo, V. V., Fedoruk, R. S., Ratych, I. B. (2012). Laboratorni metody doslidzhen u biolohii, tvarynnytstvi ta veterynarnii medytsyni [Laboratory methods of research in biology, veterinary medicine]. Lviv, Ukraine: Spolom, 762.

\section{ФИЗИОЛОГО-БИОХИМИЧЕСКИЕ ПОКАЗАТЕЛИ КРОВИ КОРОВ ПРИ СКАРМЛИВАНИИ ДОБАВКИ АКВАГИДРАТА ИОДА И ЦИТРАТОВ ХРОМА, СЕЛЕНА, КОБАЛЬТА И ЦИНКА}

\section{М. М. Цап, В. Г. Каплуненко, Р. С. Федорук, И. И. Ковальчук,}

\section{О. П. Долайчук, М. И. Храбко}

Аннотация. В статье приведень результать исследований влияния введения в рачион коров добавки аквагидрата иода и ицитратов хрома, селена, кобальта и иинка, полученных методом нанотехнологий, на течение физиологических прочессов в организме по уровню гематологических $и$ иммунобиологических показателей, а также содержание отдельных микроэлементов в крови коров. Отмечено, что включение в рачион коров добавки с аквагидратом йода и ичитратов хрома и селена (0,06 мг I 30 мкг Cr, 25 мкг Se / кг с. г. рачиона) в течении двух месячев способствовало усилению обмена гликопротеинов и их углеводных компонентов с достоверным увеличением в крови животных содержания иерулоплазмина, сиаловых кислот и гексоз, связанных с белками. Существенного влияния добавки на уровень других иммунологических и гематологических показателей не отмечено. Применение в кормлении коров в первый месяи лактации добавки, содержащей иод, хром, селен, кобальт и цинк (0,06 мг I 30 мкг Cr, 25 мкг Se, 100 мкг Со и 10 мг Zn / кг с. в. рациона), приводило к достоверному повышению содержания в крови животных меди, а во второй месяи скармливания добавки кдостоверному повышению содержания кобальта, меди и к снижению кадмия.

Ключевые слова: коровы, кровь, минеральная добавка, аквагидрат йода, 
цุитраты хрома, селена, кобальта и циинка, гемоглобин, эритроциты, общий белок, аминотрансферазы, молекуль средней массы, ииркулирующие иммунные комплексы, гликопротеины, микроэлементь

\title{
PHYSIOLOGICAL AND BIOCHEMICAL BLOOD PARAMETERS OF COWS THAT WERE FED WITH SUPPLEMENTS CONTAIN IODINE AQUAHYDRATE AND CHROMIUM, SELENIUM, COBALT, ZINC CITRATES
}

\author{
M. M. Tsap, V. H. Kaplunenko, R. S. Fedoruk, I. I. Kovalchuk, \\ O. P. Dolaychuk, M. I. Khrabko
}

Abstract. The results of research of the influence of adding to the cows diet supplements that contain Iodine aquahydrate, Chromium, Selenium, Cobalt and Zinc citrates, which were obtained by nanotechnology, on the physiological processes in the organism in terms of hematological and immunological parameters and certain microelements content in the blood cows were shown in this article. It was noted that the inclusion to the diet of cows supplements with Iodine aquahydrate and Chromium, Selenium citrates (0.06 mg I, $30 \mathrm{mcg} \mathrm{Cr}$ and $25 \mathrm{mcg}$ Se per kg dietary dry matter) within two months contributed to activate the exchange of glycoproteins and their carbohydrate components with increase concentration of the ceruloplasmin, sialic acid and hexoses bound to proteins in animal blood. Substantial influences of the additions on the level of other immunological and hematological parameters were not observed. Using in feeding cows during the first month of lactation supplements that contain Iodine, Chromium, Selenium, Cobalt and Zinc $(0.06 \mathrm{mg} \mathrm{I}, 30 \mathrm{mcg} \mathrm{Cr}$, $25 \mathrm{mcg}$ Se, $100 \mathrm{mcg} \mathrm{Co}$ and $10 \mathrm{mg} \mathrm{Zn} \mathrm{per} \mathrm{kg}$ dietary dry matter) resulted in significant increase in animal blood content of Copper, in the second month of feeding supplements - significant increase of Cobalt, Copper and decrease of Cadmium.

Key words: cows, blood, mineral supplement, iodine aquahidrat and chromium citrate, selenium, cobalt and zinc, hemoglobin, red blood cells, total protein, aminotransferases, average molecular weight, circulating immune complexes, glycoproteins, microelements 